\title{
Making Professional Decisions Account-able
}

\author{
Schrøder, Ida
}

Document Version

Accepted author manuscript

Published in:

Journal of Organizational Ethnography

DOI:

10.1108/JOE-08-2018-0037

Publication date:

2020

License

Unspecified

Citation for published version (APA):

Schrøder, I. (2020). Making Professional Decisions Account-able. Journal of Organizational Ethnography, 9(1), 110-124. https://doi.org/10.1108/JOE-08-2018-0037

Link to publication in CBS Research Portal

\section{General rights}

Copyright and moral rights for the publications made accessible in the public portal are retained by the authors and/or other copyright owners and it is a condition of accessing publications that users recognise and abide by the legal requirements associated with these rights.

Take down policy

If you believe that this document breaches copyright please contact us (research.lib@cbs.dk) providing details, and we will remove access to the work immediately and investigate your claim. 


\section{Making Professional Decisions Account-able Ida Schroder}

Journal article (Accepted manuscript*)

\section{Please cite this article as:}

Schrøder, I. (2019). Making Professional Decisions Account-able. Journal of Organizational Ethnography, 9(1), 110-124. https://doi.org/10.1108/JOE-08-2018-0037

DOI: https://doi.org/10.1108/J0E-08-2018-0037

This article is [0 Emerald Group Publishing and permission has been granted for this version to appear here: https://research.cbs.dk/en/publications/making-professional-decisions-account-able

Emerald does not grant permission for this article to be further copied/distributed or hosted elsewhere without the express permission from Emerald Group Publishing Limited.

* This version of the article has been accepted for publication and undergone full peer review but has not been through the copyediting, typesetting, pagination and proofreading process, which may lead to differences between this version and the publisher's final version AKA Version of Record. 


\title{
Making professional decisions account-able
}

\author{
Ida Schrøder \\ Department of Operations Management, \\ Copenhagen Business School, Frederiksberg, \\ Denmark \\ Correspondence \\ Ida Schrøder, Department of Operations Management, \\ Copenhagen Business School, Solbjerg \\ Plads 3,B402, Frederiksberg 2000, Denmark. \\ Email: idsc@kp.dk \\ Funding information \\ Independent Research Fund Denmark Research, \\ Grant/Award Number: 1329-00137B \\ ORCID \\ Ida Schrøder https://orcid.org/0000-0003-1358-6007
}

\section{To cite this article}

Schrøder, I. (2019), "Making professional decisions account-able", Journal of Organizational Ethnography, Vol. 9 No. 1, pp. 110-124. https://doi.org/10.1108/JOE-08-2018-0037

\begin{abstract}
Calls for financial accountability within public human service organizations have proliferated since the introduction of the so-called new public management in the 1980s (Hood, 1991). Accordingly, the production of cost accounts has been a pivotal part of service delivery for approximately 40 years. Nonetheless, from research on accountability, we know more about the consequences of new and financially oriented forms of accountability than about the practical work of producing accounts. This, at least, is the case in two practice-oriented fields of research: management accounting as a practice (MAP) and social work practice (SWP). Within these two fields of research, it is generally argued that financial forms of accountability have constrained the room for professional discretion (Kurunmäki, 1999; Banks, 2004; Munro E., 2004; Brodkin, 2011; Bracci and Llewellyn, 2012). The MAP scholars Bracci and Llewellyn (2012), for instance, warn us that the future lives of children will be jeopardised if only short-term benefits of reducing costs are taken into account in decision-making (p. 828). This begs the question of how accounts of costs and accounts of needs are practically produced and connected in the day-to-day practices of welfare professionals. The ambition of this paper is to answer this question by giving insights into the practical work proceeding moments of account-giving.
\end{abstract}




\section{Introduction}

In this paper, I describe the accounting processes and the practical work of shaping and connecting accounts of the children's needs and accounts of the costs of services, with the overall goal of making accounts durable enough to make the connections between children and costs visible to those who hold and are held accountable for the department budget. However, where most studies of accountability relations ask who is held accountable, for what and how (cf. Roberts and Scapens, 1985; Roberts, 1991; Banks, 2004; Munro E., 2004; Bovens, 2009; Brodkin, 2011; Bracci and Llewellyn, 2012; Almquist et al., 2013), I take a step back and ask how, when and where is accountability made possible in practice. I do this by tracing how professional decisions are shaped to make it possible to account for both the needs of vulnerable children and the costs of services. I view these as the practices involved in making decisions account-able. I use the word 'accountable' here (with a dash) to distinguish the work of shaping accounts from the act of 'being accountable'. Whereas the act of being accountable is most often viewed as a responsibility that lands on the shoulders of the individual (Roberts, 1991; Banks, 2004; Lipsky, 2010), I want to emphasise those practical and collective efforts that go into the work of making professional decisions account-able. My main research question is as follows: How are accounts of costs and needs shaped, connected, and made durable?

The paper proceeds as follows. First, I provide a brief review of how accountability has been studied within management accounting and social work research. Then I describe the theoretical and methodological considerations involved in the design, undertaking and analysis of the ethnographic field material. This is followed by an introduction to the empirical setting. In the empirical section, I describe how accounts of costs and needs are shaped, connected and made durable in a Danish local government. Finally, I discuss the theoretical and practical proposition of my ethnography: namely, that accountability is a socio-material and collective effort rather than an individual fight against an external force.

\section{Accountability: From external force to an ongoing, socio-material process}

"Accountability" is most often defined as a relationship that "institutionalises the rights of some people to hold others to account for their act" (Roberts \& Scapens, 1985, p. 448). How this is done and to what consequence has been studied thoroughly within the fields of MAP and SWP. In the light of New Public Management and new technologies for measuring performance and controlling costs, a particular interest has been paid to the question of how individuals are held accountable to a multiplicity of different, and sometimes even conflicting, types of accountability (cf. Messner, 2009; Bracci and Llewellyn, 2012; Dall and Caswell, 2017). Within SWP research, accountability has been studied largely as a pervasive managerial and

political external quest to constrain professional discretion by enhancing numbers-based decision-making (Munro E., 2004). Despite a variety of investigations and approaches to the concept of accountability, the SWP researchers seem to agree on one thing: That accountability has an inherent ability to transform social work practices to a point where the wrong things are made to count (Brodkin, 2011). The "new social professions" are concerned with administrative accountability work rather than "in-depth face-to-face work with individual service users" (Banks, 2004, p. 184). And professional notions of accountability are being 
subsumed by bureaucratic accountabilities, making professionals "slave[s] to the machine" (Burton and van den Broek, 2008).

MAP research mirrors research on accountability in SWP in so far as it convincingly conveys that individualization and instrumentalization push collective responsibilities and ethical concerns for individual clients aside due to the pervasive demands for financial accountability (cf. Bracci \& Llewellyn, 2012; Messner, 2009). In doing so, it also assumes that different types of accountability are pre-existing. From this assumption, it follows that it is possible to adhere to or resist certain types of accountability (Broadbent and Laughlin, 1998; Kurunmäki, 2004). However, in contrast with SWP research, MAP research theorizes accountability relations as intrinsic to the organising of professional work practices. Accordingly, MAP researchers study how different external variables - such as the financial environments (Kraus and Lindholm, 2010) and the intractability of the clients' problems (Bracci and Llewellyn, 2012) - cause the types of accountability to vary. Although both fields of research convey relevant and troubling insights into the consequences of the conflicts that arise, when professionals are called to account in multiple ways, they generally leave the actual work of producing and coordinating multiple accounts less explored.

The idea that more research into the practices underpinning accountability relationships is needed has also been commended by the renowned public policy professor Michael Lipsky (2010 [1980]). In the second edition of his seminal book on the dilemmas of "street-level bureaucrats", he suggests studying how professionals navigate multiple types of accountability, rather than critically deconstructing unsuccessful cases. This research agenda has been taken up by several SWP scholars (cf. Brodkin, 2008; Dall \& Caswell, 2017). Dall and Caswell (2017), for instance, shift attention from the analysis of conflicting types of externally imposed accountability systems to the work of internally negotiating and shaping decision-making.

Many of the assumptions inherent in the existing MAP and SWP research make it difficult to investigate the practical work that goes into making decisions account-able in multiple ways because they predefine what outcomes are being investigated. For instance, in the context of a hierarchical relationship, researchers will look for demands that come from physically different places or specific moments in time and place, where someone is held accountable. Since the aim of this paper is to gain insights into the practical work of shaping, connecting and making accounts durable, I move away from the above propositions. Instead, I mobilize the theoretical insights from constructivist accounting scholars, who suggest investigating accountability as a practical matter of making actions visible (Munro \& Mouritsen, 1996). The purpose of this theoretical approach is to openly investigate the practices that make multiple forms of accountability possible.

\section{Accountability as a practical matter of making actions visible}

Drawing on Gerfinkel's (1967) work, constructivist accounting scholars emphasise accountability as the situated practises of making everyday affairs "account-able” (Garfinkel 1967, p. 1, quoted in Munro 2001). In his view the giving of accounts is an ongoing process of making actions visible rather than an act of justifying or excusing past events (Scott and Lyman, 1968). Through this lens, accountability relations are ongoing and decentred (Munro \& Mouritsen, 1996). This has two main implications for my study. Firstly, it 
implies that accountability does not come together at a single point, such as with a manager, in a budget, with a caseworker or in a meeting. Rather, accountability involves humans as well as all the various materials that represent the organisation - documents, meeting agendas, spreadsheets - and theses materials weave in and out of each other as they produce different modes of accounting (Law, 1996; Munro, 1996, 1999, 2001). As Munro argues (2001), it is the "budget gap" and not the manager who calls the employees to account. Similarly, he suggests that it is the materiality of the accounting process "which is 'deciding' ahead which particular forms of accounts can be consumed" (Munro, 2001, p. 479). This attention to the materiality of the accountability relationship allows me to study what "enters into" (Munro, 1996, 2) and what shapes the accounts. To this end, I approach accountability as a socio-material practice.

Secondly, it implies that accountability (/ies) changes shape as it moves between various practices and that it does not start in the moment of giving an account nor does it stop after the account has been given (Law, 1996). Correspondingly, I approach accountability as mobile and fluid (Munro, 1999). This allows me to ask how the practical work of shaping accounts varies and how accounts of costs and accounts of needs are connected. In this way, I can emphasize the work of making connections between accounts that are most often assumed to be conflicting. This approach is based on the view that neither budgets nor the needs of children exist independently when they are part of professional work (Munro, 1999). Rather, the work of separating numbers from needs and needs from numbers is the result of social-material efforts just as much as the work of connecting them is (Munro, 2001). Accordingly, my investigation of connecting also involves separating (Latour, 1993; Czarniawska, 2017).

The question of how such fluid connections are made durable is the last of my three-step research question. I investigate this by approaching durability as an achievement of the ongoing work of making connections visible to accountants, managers, politicians, and others who do not take part in deciding how to spend money and meet the needs of children on a daily basis. As Robson (1992) has shown, numbers make accounts durable and mobile because they are recognisable across space and time. What I focus my attention on is how numbers are made durable when they are also connected with needs. In other words, what makes connections between costs and needs hold?

\section{A symmetrical approach to the study of accountability}

I spent approximately 400 working hours in 2016 and the beginning of 2017 following the accounting processes in and across a child protection- and an accounting department in a Danish local government. My fieldwork approach resembled a "symmetrical ethnology", as Czarniawska terms it (2017), where I was observing practices rather than cultures, following how appropriations of social services took part in shaping, connecting and making accounts durable. I started out in the child protection department, where I followed caseworkers in their work of assessing the needs of children, reaching decisions about which services to provide, and accounting for the steps they took along the way. Whenever possible, I would then follow the process of appropriating a service as it moved back and forth between the child protection department and the accounting department. 
This strategy was not straightforward. Most importantly, it required access to private information. This access was approved by the Danish Data Protection Agency and by the individual children and families. However, 'access' was also practically constrained by my ability to be present at the specific moment when the caseworker appropriated the services. When these circumstances were in place, I would go to the accounting department and continue to follow a specific appropriation or simply follow other appropriations. What I did specifically was to ask caseworkers and accountants to let me see what they did when they appropriated services, assessed the accuracy of cost estimates, paid bills, allocated costs, etc. While I observed them at work, I sometimes interrupted them and asked what was going on. At a later point in time, I would ask them to tell me how it went with particular appropriations. To this end, I did what Czarniawska (2014) defines as "observant participation": I talked to key informants about what had happened with the appropriation since we had last spoken. In this way, I made the appropriation 'talk'. I often recorded such conversations in order to be able to talk more freely, instead of writing while talking. I also participated in budget meetings, department meetings and various 'work meetings' on the relationship between caseworkers' decisions and the corresponding accounts. Overall, this amounted to about 350 pages of computer written field notes, observations of 46 meetings, 90 hours of shadowing caseworkers and appropriations, more than 100 recordings, from which 33 were planned interviews, as well as numerous documents and photos.

\section{Empirical setting}

I undertook the fieldwork in the area of child protection work because I knew this was an area where demands for accountability had increased during the previous 10 years. $37 \%$ of Danish children received social services in 2017 at a cost of $€ 2,5$ bn. (DKK 18,2 bn.). By way of comparison, this is one third of the annual budget for all social services and $25 \%$ less than the cost of day care for all children in Denmark. According to Statistics Denmark, these numbers have been stable for about ten years (Statistics Denmark, 2018). Even so - or possibly because of this - the relationship between costs and needs are continuously under scrutiny and is a topic of political controversy and reform. While a decentralisation of the public finance system in 2007 designated the full responsibility for financing and delivering statutory services to citizens with the local governments (The Danish Government, 2007), the government also implemented a financial fining system to prevent the overspending of local public budgets (The Ministry of Finance, 2012). With this regulation, any overspending of service costs would accumulate to even more overspending the following year. Correspondingly, the Danish government and the local governments developed and implemented new IT systems, organizational models and tools in order to support better accounting procedures and increase cost efficiency.

Meanwhile, the Danish child protection system went through a transformation from family oriented to child oriented decision-making procedures (The National Board of Social Services, 2011). As a part of the Scandinavian welfare model (Esping-Andersen, 1996), the child protection services are aimed at giving "children in need" the same opportunities as their peers, by both protecting them from harm as well as preventing future harm. This concerns children and youth who have been neglected, mistreated or sexually and/or physically abused, as well as children and youth who, for reasons associated with poverty, mental 
issues or lack of parental abilities, are not developing at the same rate as their peers (Social Service Act, 2018). This transformation towards the 'child first' focus was aimed at securing the rights of the children. While the constraints of the budget law and the 'child first' agenda seems to be pulling in opposite directions - the first aimed at reducing service costs by standardising procedures and the second aimed at individualising service provisions and, as a result, possibly increase service costs - statutory caseworkers, nonetheless, are asked to take into account both of these agendas when they decide and account for their choice of service provision (Social Service Act, 2018).

The decision-making processes are organised in a so-called purchaser-provider split (Siverbo, 2004; Nørrelykke, Zeeberg and Ebsen, 2011), where child protection caseworkers (caseworkers) order the social services from private and public service suppliers. Ranging from a few hours per month of individual support for a child to full-time placement- and treatment, the services also vary greatly in cost. Deciding which service to buy is a meticulous process without certainty or the possibility of verifying whether the best choice has been made. Accordingly, the work of accounting for the reasoning behind the choice of service is a pivotal part of the decision-making process. To paraphrase Munro (1996, p. 5), decision-making is "organized to be 'read' by other members". The steps to take in such decision-making procedures are regulated by law, but it is up to the local government to organize the procedures and to decide on the level of funding for the various service areas. In most local Danish local governments, including the one where I did my fieldwork, the full responsibility for a service area budget is given to the top management so that money can be moved from one department to another. As long as the overall service costs stay within the overall budget limit, the local government is not financially penalized. In the case of departmental budget discrepancies, however, it is up to the local politicians to decide whether the department budget should be adjusted.

Since it is difficult to predict how a child's life will play out, it is also difficult to predict the costs of the services required to help and support children in need. Instead, the accounting department - and the accounting procedures - look back at the costs of services from earlier years and compare them, month by month, with the costs of the present (Schrøder, 2014). When the accountants see discrepancies between last year's accounts and the present year's accounts, they take it as a sign that something is not as it should be. It could both be a sign that the accounting numbers are inaccurate and that the amount of money spent on services differs from the previous year. Accordingly, the process of producing accurate accounts of costs becomes key in the work of assessing the relationship between costs and needs. The ethnography conveyed in this paper centres around this work.

\section{Making professional decisions account-able}

I have divided the material into three parts: I start out by analysing how accounts of costs and needs are shaped into different forms of accounts. In the following step, I analyse how accounts of costs and accounts of needs are connected. In the third step, I analyse how connections between costs and needs are made account-able - with a dash to underscore that it is not enough to establish connections; the connections also have to be made durable. 


\section{"That is too much money flying around"}

One afternoon in October 2016, I was sitting in on a weekly meeting between the economic consultant, Eva, and the accountant, Marlene. They were conversing about the tasks of the week when Marlene mentioned that she had heard from her colleague that three children had been abruptly placed in a local out-of-home facility a few weeks earlier. In shock, Eva opened her eyes and mouth widely and replied: "That is half a million kroners ${ }^{1}$, at least!" She then explained her train of calculations: Each placement costs DKK 100,000 (EUR 15,000) per month. If the children had already been there for two weeks, then a month and a half would quickly pass before they found a permanent solution. "That is too much money flying around," she added. She then went on to explain how she could bring the money into the quarterly report by adding the estimated costs "by hand". "Adding by hand is problematic," she said and explained further: The problem was not that it was less accurate; the problem was that it generated more subtasks for her budget control, and that it made future adjustments more fragile. It also signalled to her that the caseworker did not take the responsibility of making the appropriations seriously. Nevertheless, she had to finish the quarterly reports within the week, so adding it by hand was a better choice than waiting for the appropriation of the costs.

Two days later, as I entered the open office space of the caseworkers, I was surprised to see two rows of papers lined up on the very long table in the middle of the room. 46 sets of papers, each held together by paperclips and numbered with Post-It Notes. "Those are the attachments for Maya's report to the Child Protection Committee," a caseworker told me. I walked to Maya's desk. With papers all around her and clearly very busy, she looked at me: "I have to lay out the attachments; otherwise, I lose track. Cathrine [her manager] told me to add more documentation". She had found some, and now she was revising the numbering and the reference list. The report was due in an hour. She was too busy to answer any more questions. I did not have to ask her to know that this was the case where money was "flying around": Three children had been unexpectedly taken away from their parents and placed in a temporary housing facility. The child protection department had received notice of violence in the family and had reacted according to the Social Service Act and their local guidelines. Now Maya was preparing the case files to be presented at the Child Protection Committee meeting, where a judge would make a statutory decision about whether or not there was sufficient documentation to place the children in an out-of-home facility without consent from their parents. When I talked to Maya the following week, she told me that although she was aware that the three acute placements would be a large expenditure, she still had not appropriated the costs of them. She would get it done as soon as possible.

At that point, I had been in the municipality for about half a year, and neither the work of preparing case files for decision meetings nor the work of appropriating and allocating costs were strange to me. However, as I was confronted with Maya's attachments on the table (and realized it was the case with the missing appropriations), the distinctiveness of shaping accounts of the needs of the children and accounts of the costs of services stood out. The account of needs made use of a storyline of traces of violence as a means to

${ }^{1}$ EURO 67.000 
provide evidence for the legality of taking the children from their parents. This evidence reached back in time and stretched out across places and people in the lives of the children. Here, the question is: Which and how much evidence should be included? In this case, the manager calls for more evidence. She might as well have told Maya that more evidence made their claim about the needs of the children stronger. Accordingly, there is discretion in the process of producing the account of the needs, where choices are made in regards to where and how to collect - i.e. shape - the evidence of the needs of the child. In this sense, the account of needs represents one version of several possible versions of the 'truth' about the needs of the child. In this particular case of acutely taking three children away from their parents, a Child Protection Committee tests the legality of the discretionary account of the needs of the children. In other words, if Maya's version of the needs is not convincing, then the decision to remove the children is illegal. This is why "more documentation" is needed, even though the time window for finishing the report is one hour.

Two days before I saw the account of needs lying on the table, the economic consultant had said: "That is too much money flying around". As Maya was working against the clock to finish her account of the needs, the economic consultant entered the costs of the children's placement in the spreadsheet with accounts of costs of services "by hand". This means that the account of costs started to take shape - first as money flying around and then as specific numbers in a spreadsheet - even before Maya made the account of them. Through this process of shaping the account of costs into an entry in the spreadsheet the economic consultant made it possible for others besides Maya and her supervisor to see that the money had been spent. Although the economic consultant found it problematic to do this "by hand", it was, nonetheless, in her opinion, better to have the costs entered into the spreadsheet than to have them flying around. To this end, the account of costs had more to do with procedures for making costs accurate and stable than with discretionary choices in regards to how and what to account for.

The coincidence of meeting two distinct accounts of the same decision at separate places and almost at the same time is illustrative of three points. First, it illustrates that accounts start to take shape even before the decisions are final. Second, it illustrates that the shape of accounts is prefigured by spreadsheets, legislation, procedures, etc. Third, it illustrates that even though they are accounts of the same decision, they shape the decision into being about two different matters: the account of needs shapes the decision into a matter of documenting the needs of the children, while the account of costs shapes the decision into a matter of specifying the accurate costs of services. Although Maya's case, where three children were acutely removed from their parents, is unusual, these three characteristics of the shape of accounts are also present in decisions regarding children in need of other kinds of social intervention. The question now is: How are these two different ways of making decisions account-able connected? We have seen that the two accounts take shape even before the costs have been accounted. In order to learn how they, more practically, are connected, then, we have to look into what happens to the relationship between the account of needs and the account of costs in the process of appropriating the costs of services. 


\section{Separating costs from needs}

In 2016, 585 children received services from the child protection department. Sometimes children are granted a single service, and accordingly, only one cost account is made. It is not unusual that children with severe and complex needs, though, are granted 10-20 different services and benefits throughout a year, where each service is allocated as a cost item to a specific legal paragraph that grants the child protection department the right to cover the expenses.

The first step in the process of shaping cost accounts takes place on the computer screen of the caseworkers as they allocate each element of the decision to grant a service to the correct legal paragraphs. At first, I thought this was a simple task of selecting from predefined alternatives. What I saw, though, was a system of various numbers, each representing a particular aspect of the decision to provide a social service. Foster families, for instance, come in three categories, and each foster family is assigned a number that corresponds to their geographical location, not to speak of the social security number of the parent who is to receive a particular number of remunerations for fostering the child. Apart from this, the foster family, as well as the biological parents, are often granted supplementary benefits such as money for transportation and birthday presents. Additionally, services are always provided for a limited amount of time, and sometimes from a random day in the month, which means that cost estimations are calculated by the day, the week and/or the month. So, even though only one legal paragraph (Social Service Act 2014, \66,1) gives the child protection department the right to grant "foster family" as a social service, a whole range of other numbers are used as means to account for the costs.

Since many costs are regulated by national tariffs, I also expected the calculation of, say, psychological treatment to be a straightforward task. Sometimes though, the contracts are not made in time for the service to be provided. Or the number of, say, family therapy hours is regulated along the way and require a new appropriation. Even when there is a contract with a set price, sometimes the price in the contract deviates from the price registered in the database. This leaves the caseworkers with the choice of following the costs in the contract or the costs in their local accounting database. In this sense, the act of calculating the costs involves many different elements, including national tariffs, the accounting database, inflation, the private economy of parents, the number of days in a month, etc. The calculations of cost estimations are not always as straight forward as they could be.

The costs remain in the same IT system, together with the story of the children's lives in a column right next to the column that states the duration of the social service. The account of the costs begins to take shape when the caseworker informs the accountants that costs for a service has been granted. Picture a 27-inch monitor with a 2x2 inch window in the middle. In this window the caseworkers enter the details of the appropriation. All the numbers mentioned above go into this space: The estimated cost calculation, the exact time period for the payment, social security numbers of the child, as well as the person receiving the salary, headings, as well as legal paragraphs and supplementary information in the case of state reimbursements or other particularities. There is no room for long words. Even "and" is abbreviated with "/”. By now, the cost account consists almost entirely of numbers - numbers that represent aspects of the decision to grant a social 
service. When approved, the accounts automatically pop up on Marlene's (one of the accountants) screen. Now, the account of costs has no trace of the needs of the child who has been granted a service. In other words, the costs that started to take shape on the same screen as the needs of the child are transported to a different location - they are separated from the needs.

\section{Assessing the accuracy of cost accounts (to the tunes of pop music)}

As the notice of an appropriation reaches Marlene's screen in the accounting department, it is an account of costs. Marlene starts the process of assessing its accuracy: To begin with, she makes sure that there are no discrepancies between the estimated cost in the notice of the appropriation, the price in the contract, and the price in their database of suppliers. This process physically takes place in office 1207 , where the radio is always playing pop music. One time, as Marlene is struggling to work out why the estimated costs for a service does not match the listed costs in the accounting database, Michael Jackson intones on the radio: "Go on girl heheheee..." and Phil Collins obligingly follows up with "just give me one more night...". Marlene, though, does not have one more night. Much to her own regret, she gives up on solving the mystery of the discrepancy and simply adjusts the listed costs to match the estimated costs. The discrepancy is minimal, she tells me: It is more of a matter of principle than a problem in the accounting procedures. When she considers the cost accounts to be accurate, she copies them into the accounting database and allocates them to a specific line item. In doing so, the costs enter Eva's (the economic consultant) spreadsheets and await estimation as a future expenditure.

The music made my work of talking, observing and writing more complicated, but the accountants told me that it helped them work. Specifically, Jane, who was in charge of paying the bills, said she needed the music to get the work done. She explained to me that it helped keep her in a good mood. Marlene also assured me that the radio was essential to her work. It seemed I was the only one troubled by the music. In time, though, I learned to appreciate it, and I found myself dropping by their office, enjoying the pop music as a break from the seriousness of the child protection work. As I did so, I started noticing how it supplemented the mundane, detail-oriented and repetitive tasks of paying bills and allocating costs.

With the appropriations in the database, Marlene's colleague Jane can make the payments to the suppliers of services. When doing so, she compares the price on the invoice with the costs in the accounting database. In cases of discrepancies of more than $5 \%$ or DKK 5000 , she has to stall the payment. Correspondingly, when a caseworker has not appropriated the costs, the suppliers of services are not paid. Instead, Jane enters the information from the invoice on a list of "Invoices without appropriations" and informs the particular caseworker that she is waiting for her cost appropriation. Jane, humorously but with a grain of seriousness, calls this list "The black list". Because, as she explains to me, the list contains the names of caseworkers who prevent her from doing her job. When she clicks her way back and forth between accounting systems, emails, invoices and spreadsheets, it looks and sounds as if she is trying solve a grand mystery. She turns her head towards me with raised eyebrows and says: "This is why I need some music". When "The black list" gets too

long, she emails it to a supervisor, who then personally asks the caseworkers to make their appropriations. 
Only after Marlene has received the appropriation, approved it and coloured its row in "'The black list" green can Jane finally delete the row from the list and pay the bill.

After the accounts of costs are meticulously separated from needs and their accuracy is assessed, can the numbers move around as payed bills and allocated costs. When bills are payed and costs are allocated, the costs and needs are re-connected: In the former process, they are re-connected by being present at the place of the social intervention - with the foster family, the placement supplier, the psychological treatment and so forth. In the latter process, they are re-connected in the shape of number-based cost accounts and line items representing the various service provisions aimed at meeting the needs of the children. This, however, is also not a simple task. In the following, we will explore why not.

\section{A temporary re-connection of cost and needs}

The process of re-connecting the account of costs with the line items in the purchasing budget takes place on the computer screen of the economic consultant, Eva. With the appropriations in the accounting database, she can upload the numbers into the budget, see how much was spent, and compare it with the estimated expenditure. She does this every quarter, a few weeks before the quarterly report is due. As I sit down with her one day in October, she shows me how: She opens up a spreadsheet (one of many) with "activity numbers" on all the types of services the caseworkers can grant. She points with the cursor to the number of placements in 2016 and shows me that it is lower than in 2015. "In August [2016], it was 75, and I knew it was supposed to be about 100," she says. Next, she clicks on the update icon, pauses for a moment, and the numbers change. The number of placements is now 95. Still not satisfied with the number, she says: "Compared to what I have heard from [the child protection department], there should be more placements recorded in the system [than last year]". She decides to do some extra work to double check it. In a new spreadsheet, she makes a list of recorded placements, including the ones with an expired appropriation, and asks Sahar, one of the supervisors from the child protection department, to go through them and add comments if there have been any changes.

Sahar describes the process of going through the list as a standard procedure that take place at least every three months. She looks down the list and says that she knows most of the placements by memory. She adds a few pieces of information, such as "this is to be extended", "this one has ended", "he moved home", and so forth in the column for her comments. This, she explains, gives Eva the most up-to-date information. In this sense, the list - and similar lists - temporarily replaces the appropriations by bringing the adjusted costs directly to Eva. This is what happens when appropriations are delayed or "missing", as the accountants say. The lists provide a temporary separation of needs and costs, which gives Eva the opportunity to manually, "by hand", add and subtract changes in the cost allocations in due time for the quarterly report. Although, this works as a quick fix, it also makes the process of estimating the future expenses fragile because the costs might be different after their accounts have been made. Also, without visible traces of which needs the costs are associated with, it is neither possible to assess their accuracy nor to re-connect with the needs as paid bills. 
When the choice to grant a service is represented as numbers, it looks stable and unquestionable. Nonetheless, throughout the process of appropriating and allocating the costs, the numbers are continuously questioned and changed. Eva questions the numbers by comparing them with past expenditures. In case of discrepancies, she tries to improve the numbers by updating them according to her knowledge of the specific case. Here, the production of new numbers is pivotal. As Munro points out "numbers can consume other numbers" (Munro, 2001, p. 486) insofar as they make the discrepancy smaller. It is not enough that the supervisors have told Eva that more placement services have been granted compared with last year. Only the activity and costing numbers can consume the discrepancy. In this way, the lists of new numbers help Eva improve the accuracy of the cost accounts "by hand". But the discrepancy between past and present remains. Why does this bother Eva so much? Because it signals that she is lacking the numbers that can explain - i.e. consume - the discrepancy. The problem, however, is not that there is a discrepancy between past and present expenditures, but that there is a discrepancy between what she has been told about the needs of the children and the accounts of costs. In other words, the problem is that the connection between accounts of needs and accounts of costs is unknown.

\section{A failed attempt to make accounts durable}

Throughout October and November, Eva becomes increasingly concerned about the accuracy of the accounting numbers. As the end of the year is approaching, the accountants talk about the flow of incoming invoices without appropriations as "endless". "The black list" of December $17^{\text {th }}$ testifies to 140 invoices waiting for appropriations. As I talk to Marlene and her colleague in January 2017, the feeling of apprehension stemming from not being able to dispatch the appropriations was still in the office. They complain to me that a supervisor from the child protection department warned them to put more pressure on the caseworkers because the caseworkers were already under so much pressure that "they were almost crying". "But," Marlene's colleague confessed, "we were crying on that Friday afternoon when the invoices did not stop coming in."

In the child protection department, they seem to be caught by surprise, as the annual report states that they - for the first time in eight years - have overspent their purchasing budget. With a tone of seriousness, the manager informs the caseworkers about it at a department meeting in January 2017. She tells them that there are many possible explanations for why they have overspent. What bothers the manager the most, she says, is that she and the accountants were not able to predict the overspending and act to prevent it. "Half a year ago, we were expecting to spend less than the budget," she tells them. Her explanation for why they did not know about the overspending was that the appropriations of costs had not been timely and accurate enough. In her own words:

"I have to be sure that you are aware that, even though 'appropriations' sound like the world's most boring thing, it has an indirect influence on how we help children and young people in our local area. It is super important. (...) If you tell me you have to choose, as in "should I react in this acute case or should I make the appropriations?", then, of course, you have to take the acute case. But it is still connected." (recording of department meeting) 
Even though she emphasizes the importance of the "connection" between appropriations and the needs of the children, the connection remains somewhat abstract. The manager explains that if she had been able to predict the overspending, then they could have better adjusted their choices and delimitations of services along the way. "Even five hours here and five hours there make a difference [to the overall costs]," she says. The consequence of not knowing, she speculates, will be a future with more control and more standardised decision-making. The point here is that there is a difference between needs and costs being connected in the decisions regarding individual children and overall needs and costs being connected "in our local area". When the connection is not made know-able to others - such as the accounting department - then it is not possible to assess the accuracy, make the costs move as payments of bills, allocate the costs to line items and estimate future expenditures. To use the metaphor of the economic consultant, the money will be flying around until the caseworkers and the accountants find a way to gain accuracy and stability. This might, as the manager speculates, involve more standardised procedures for decision-making and accounting and less room for discretion. Accordingly, a loss of accuracy is also a loss of discretion.

Now, we get to the point that makes the dash in account-able important. The dash underscores that it is not enough to establish connections between needs and costs, it also has to be possible (able) to account for the connection. It has to be made durable. In 2016, the connections were not made durable because not all accounts of costs were shaped into the form of numbers and when they were, they were not accurate enough. Although it is tempting to interpret this inaccuracy as an attempt to preserve discretion and prevent cost information from driving professional decisions (cf. Kurunmaki, Lapsley and Melia, 2003), I am convinced that this was not the case. The caseworkers did not individually choose to make inaccurate cost accounts. Rather, the inaccuracy was a result of the collective and socio-material process of shaping cost accounts into a different format than accounts of needs.

Whereas accounts of needs are shaped to stay in the child's case files, accounts of costs are shaped to move information around. This is the first reason why they are difficult to make. The numbers do not only specify the costs, they also specify how, where and when to move the costs. One of the difficulties is fitting so much information into a $2 \times 2$-inch space. The second reason is that the connection is made durable by shaping cost accounts into a format that first separates the costs and then re-connects them in the form of estimations of overall needs and costs. This is a fragile and ongoing process, where the re-connection can only be achieved after the accuracy of the cost account (and the separation) has been guaranteed. In this process, the cost account leaves traces behind, which make it possible to trace back how the individual needs and the costs were first connected and, accordingly, how to re-connect the costs with needs as activity numbers. The more traces this process leaves behind, the more visible the process of separating needs and costs and, therefore, the connection between them. When numbers associated with costs are added and subtracted "by hand", the traces are minimal, and it becomes difficult or even impossible to retrace connections - such was the case when Marlene tried to resolve a discrepancy to the tunes of Michael Jackson and Phil Collins. 


\section{Concluding discussion}

I have six points to make in my concluding discussion. The first three pivot around the answers to my threestep research question: How are accounts of costs and needs shaped, connected and made durable. The following two points regard the theoretical implications for studies of accountability relations. And, the sixth point regards the practical implications for practitioners - caring professionals, managers, as well as accountants - in human service organizations.

Shaping: Most importantly, my ethnography shows that individual caseworkers do not shape accounts. Rather, the accounts were shaped by countless actors - spreadsheets, legal paragraphs, national tariffs, instances of violence, activity numbers, IT systems, lists, caseworkers, managers, accountants, etc. - all working together to make decisions account-able in two distinct ways. The account of costs started to take shape as costs were calculated. The account of needs took shape as stacks of paper. Numbers, specifying the costs and how to move them around, made up the first account. Pieces of paper, documenting physical violence against three children, made up the second. Not only did they look different, they also represented two distinct modes of accounting for the same decision: The first specified information, by making it as accurate as possible. The second documented information, by attaching as much as possible. Whereas as little as possible entered into the first, as much as possible entered into the second.

Connecting: To begin with, the costs and the needs are both considered when making a decision regarding an individual service provision. More specifically, they both start to take shape as information is entered into the child's casefiles. When the caseworker sends the notice to the accountant that costs have been appropriated, the costs start to move. They are being separated from the needs. This, however, is only a temporary separation. In the process of appropriating the costs, the traces of connections between costs and needs are made visible by including them in the numbers. This is what allows them to be re-connected as payments to the suppliers of services and as activity numbers documenting what caseworkers do to meet the needs. In the process of separating and re-connecting, the account of individual needs stays in the child's case files. This is why, I write about the relationship between needs and costs as a process of connecting and separating and not of, for instance, transforming the needs of the children into costing numbers (Kurunmäki, 1999; Munro E., 2004).

Durability: In so far as the budget is an account of not only the costs, but also of the activities of meeting the needs of children, the connections between accounts of costs and needs are durable when the budget is aligned with the activities implemented by the caseworkers. Conversely, the connection has failed when costs and activities are not aligned. In this case, the budget discrepancy calls for more accounts of numbers as a means to explain the gap (Munro, 2001). I have made the points that numbers specify information, move information around and make connections traceable. This is why they are so successful in making the connection between costs and needs durable. Correspondingly, when cost accounts are missing, the money appears to be flying around. Even when the economic consultant tries to explain the gap by moving costs around "by hand", the connection falls apart because it leaves too few visible traces. This then, is the main proposition of the paper: Connections between costs and needs are made durable by making the traces of 
the connection visible. To paraphrase Munro and Mouritsen (1996), accountability is a practical matter of making traces of action visible.

Theoretical implication: Critical scholars have convincingly shown that a consequence of increased demands for financial accountability is that measurements become disconnected from practices by making the wrong things count (Bracci and Llwellyn, 2012; Brodkin, 2011; Munro E., 2004). Although, I do not doubt that number-based forms of accounting have increased over the years, my research shows that the practical work of producing oversight of - or of measuring - the overall costs could only produce accountability when it was connected with the needs of the children. This mirrors the argument of Law (1996); namely that accountability is achieved by connecting elements that would otherwise remain separated and unrelated. As conveyed in this paper, this is done by continuously connecting, separating and re-connecting accounts of costs and needs. This furthermore means that the boundaries between different kinds of accountability such as managerial, financial or professional accountability - are blurred in the practical work of producing accounts. Correspondingly, it is difficult in practice to be accountable to the one or the other type of accountability. Rather, being accountable to multiple and sometimes conflicting demands of accountability is a practical matter of making decisions account-able in multiple ways.

Most importantly, the story of the unexpected budget discrepancy reveals that a loss of accuracy also means a loss of discretionary decision-making. By now, the critical scholar will probably be thinking that this supports the argument that technical means of creating accuracy are pushing aside discretionary judgement (Banks 2004). I do not deny that this is possible. However, the present ethnography reveals that if this is the case, then it is the result of the missing connections between the two modes of accounting. It is not because the accounting department has an expectation that accurate numbers give a full understanding of the performance of the child protection department (cf. Brodkin 2008, p. 332). Nor is it because, caseworkers strategically cultivate invisibility as a means to preserve discretion (cf. Kurunmaki, et al, 2003). Rather, the ability to see a problem allows for the possibility of making discretionary decisions about cost allocations as well as service provisions. As Munro (1999) argues, management accounting "creates more than records which are durable" (p. 442) they also create “a continuous redistribution of 'discretion' within the organization" (p. 442). In light of the proliferated demands for accountability, it would be fruitful for researchers to ask how, when and where discretion unfolds, instead of a priori assuming the relationship between calculation and discretion to be asymmetric. And conversely to render discretion dominated by an abstract quest, an unreachable illusion, or a logic that somehow conspires with managers and accountants to make a machine out of discretionary decision-making.

Practical implications: I saw two distinct practices that shaped accounts in very distinct manners, and I saw accountants as well as caseworkers do the best they could to make the connections account-able in various ways. This work was simultaneously mundane and strenuous. The accountants needed their pop music to support their detail-oriented tasks, and the caseworkers "were almost crying" as they worked against time. Nonetheless, accountants as well as caseworkers continuously tried to make the connections between costs and needs durable, because - this is my proposition - that was how they could produce more space for discretion. By skilfully combining the two modes of accounting, it is possible to make decisions account-able 
to multiple demands and produce room for discretion. This is what was "missing" in the year I followed accounting processes in the Danish local government. And this is also why accounting is not "purely administrative", as one of the reviewers of this paper suggested. The practical implication of this proposition is that professional decisions are not made more account-able by rationalising them but by acknowledging and developing the skilful work of combining multiple and sometimes conflicting modes of accounting.

\section{References}

Almquist, R., Grossi, G., van Helden, G. J. and Reichard, C. (2013) 'Public sector governance and accountability', Critical Perspectives on Accounting, 24(7-8), pp. 479-487. doi: 10.1016/j.cpa.2012.11.005.

Banks, S. (2004) Ethics, Accountability and the Social Professions. Palgrave Macmillan.

Bovens, M. (2009) 'Public Accountability', The Oxford Handbook of Public Management, pp. 1-30. doi: 10.1093/oxfordhb/9780199226443.003.0009.

Bracci, E. and Llewellyn, S. (2012) 'Accounting and accountability in an Italian social care providor Contrasting people-changing with peopl-processing approaches’, Accounting, Auditing \& Accountability Journal, 25(5), pp. 806-834. doi: https://doi.org/10.1108/09513571211234268.

Broadbent, J. and Laughlin, R. (1998) 'Resisting the "new public management"': Absorption and absorbing groups in schools and GP practices in the UK", Accounting, Auditing \& Accountability Journal, 11(4), pp. 403435. doi: 10.1108/09513579810231439.

Brodkin, E. (2008) 'Accountability in Street-Level Organizations', International Journal of Public Administration, 31(3), pp. 317-336. doi: 10.1080/01900690701590587.

Brodkin, E. (2011) 'Policy Work: Street-Level Organizations Under New Managerialism', Journal of Public Administration Research and Theory, 21(Supplement 2), pp. i253-i277. doi: 10.1093/jopart/muq093.

Czarniawska, B. (2014) 'Why I think shadowing is the best field technique in management and organization studies', Qualitative Research in Organizations and Management: An International Journal. Edited by P. Seonaidh McDonald and Professor Bar, 9(1), pp. 90-93. doi: 10.1108/QROM-02-2014-1198.

Czarniawska, B. (2017) 'Organization studies as symmetrical ethnology', Journal of Organizational Ethnography, 6(1), pp. 2-10. doi: 10.1108/JOE-12-2016-0023.

Dall, T. and Caswell, D. (2017) 'Expanding or postponing? Patterns of negotiation in multi-party interactions in social work', Discourse and Communication, 11(5), pp. 483-497. doi: 10.1177/1750481317714119.

Esping-Andersen, G. (1996) Welfare States in Transition: National Adaptations in Global Economies, London, Sage.

Hood, C. (1991) 'A Public Management for all seasons?', Public Administration, 69(1), pp. 3-19. doi: 10.1111/j.1467-9299.1991.tb00779.x.

Kraus, K. and Lindholm, C. (2010) 'Accounting in Inter-Organisational Relationships within the Public Sector’, in Håkansson, H., Kraus, K., and Lind, J. (eds) Accounting in networks. New York: Routledge, pp. 113148. 
Kurunmäki, L. (1999) 'Making an accounting entity: the case of the hospital in Finnish health care reforms', The European Accounting Review, 8(2), pp. 219-237. doi: 10.1080/096381899336005.

Kurunmäki, L. (2004) 'A hybrid profession-the acquisition of management accounting expertise by medical professionals', Accounting, Organizations and Society, 29(3-4), pp. 327-347. doi: 10.1016/S0361-3682(02)000697.

Kurunmaki, L., Lapsley, I. and Melia, K. (2003) 'Accountingization v. legitimation: a comparative study of the use of accounting information in intensive care', Management Accounting Research, 14(2), pp. 112-139. doi: 10.1016/S1044-5005(03)00019-2.

Latour (1993) We have never been modern. New York: Harvester Wheatsheaf.

Law, J. (1996) 'Organizing accountabilities: ontology and the mode of accountability', in Accountability: Power, Ethos and the Technologies of Managing. International Thomson Business Press, pp. 283-306.

Lipsky, M. (2010[1980]) Street-level bureaucracy: Dilemmas of the individual in public services. 2nd edn. Russell Sage Foundation.

Llewellyn, S. (1998) 'Boundary work: Costing and caring in the social services', Accounting, Organization and Society, 23(1), pp. 23-47. doi: 10.1016/S0361-3682(96)00036-0.

Messner, M. (2009) 'The limits of accountability', Accounting, Organizations and Society. Elsevier Ltd, 34(8), pp. 918-938. doi: 10.1016/j.aos.2009.07.003.

Munro, E. (2004) 'The Impact of Audit on Social Work Practice', British Journal of Social Work, 34(8), pp. 1075-1095. doi: 10.1093/bjsw/bch130.

Munro, R. (1996) 'Alignment and identity work: the study of accounts and accountability', in Accountability: Power, Ethos and the Technologies of Managing. International Thomson Business Press, pp. 1-20.

Munro, R. (1999) 'Power and Discretion: Membership Work in the Time of Technology', Organization, 6(3), pp. 429-450.

Munro, R. (2001) 'Calling for accounts: numbers, monsters and membership', The Sociological Review, 49(4), pp. 473-494.

Munro, R. and Mouritsen, J. (1996) Accountability: Power, Ethos and the Technologies of Managing. International Thomson Business Press.

Nørrelykke, H., Zeeberg, B. and Ebsen, F. (2011) Myndighed og leverandor - Samspil og aftaler $i$ socialt arbejde med udsatte born og unge. Professionshøjskolen Metropol.

Roberts, J. (1991) 'The possibilities of accountability', Accounting, Organizations and Society, 16(4), pp. 355-368. doi: 10.1016/0361-3682(91)90027-C.

Roberts, J. and Scapens, R. (1985) 'Accounting systems and systems of accountability — understanding accounting practices in their organisational contexts', Accounting, Organizations and Society, 10(4), pp. 443-456. doi: 10.1016/0361-3682(85)90005-4. 
Robson, K. (1992) 'Accounting numbers as "inscription": Action at a distance and the development of accounting', Accounting, Organizations and Society, 17(7), pp. 685-708. doi: 10.1016/0361-3682(92)90019-O.

Schrøder, I. M. (2014) Budgetblikket $i$ socialt arbejde med udsatte born og unge. Frederiksberg: Professionshøjskolen Metropol, Institut for Socialt Arbejde.

Scott, M. B. and Lyman, S. M. (1968) 'Accounts', Americal Sociological Review, 33(1), pp. 46-62. doi: $10.2307 / 2092239$.

Siverbo, S. (2004) 'The purchaser-provider split in principle and practice: Experiences from Sweden', Financial Accountability \& Management, 20(4), pp. 401-421. doi: 10.1111/j.1468-0408.2004.00201.x.

Social Service Act (2018), LBK nr. 1114 af 30/08/2018. Available at: https://www.retsinformation.dk/forms/R0710.aspx?id=202239 (Accessed: 7 March 2018).

Statistics Denmark. (2018) StatBank Denmark. Available at: www.statistikbanken.dk/esspros1 (Accessed: 8 February 2018).

The Danish Government (2007) Kommunalreformen 2007. Available at: https://oim.dk/arbejdsomraader/kommunal-og-regionaloekonomi/kommunale-opgaver-ogstruktur/kommunalreformen-i-2007.aspx (Accessed: 22 July 2018).

The Minestry of Finance (201b) Budget Act - handout. Available at: http://www.fm.dk/nyheder/pressemeddelelser/2012/03/regeringen-indgaar-aftale-om-nybudgetlov/ /media/Files/Nyheder/Pressemeddelelser/2012/03/Budgetlov/budgetlov_handouts.ashx. (Accessed: 8 February 2018)

The National Board of Social Service (2011) Handbog om barnets reform. 2nd edn. Servicestyrelsen. 